\title{
Effect of Micronutrient Application on Growth, Fruit Retention and Shelf Life of Kinnow (Citrus reticulata Blanco.) Mandarin under Rainfed Conditions
}

\author{
P. Kumari ${ }^{1}$, M. Jamwal ${ }^{1}$, N. Sharma ${ }^{1 *}$, V. B. Singh ${ }^{2}$ and N. Gupta ${ }^{2}$ \\ ${ }^{1}$ Division of Fruit Science, SKUAST-J, Chatha, J\&K, India \\ ${ }^{2}$ Rainfed Research Sub-Station for Sub-tropical Fruits, SKUAST-J, Raya (Samba) J\&K, India \\ *Corresponding author
}

\section{A B S T R A C T}

\begin{tabular}{l} 
Ke y w o r d s \\
Kinnow, \\
Micronutrient, \\
$\begin{array}{l}\text { Shelf-life, Rainfed, } \\
\text { Citrus reticulata } \\
\text { Blanco }\end{array}$ \\
\hline Article Info \\
\hline $\begin{array}{l}\text { Accepted: } \\
\text { 22 July } 2020 \\
\text { Available Online: } \\
\text { 10 August } 2020\end{array}$ \\
\hline
\end{tabular}

Productivity of citrus trees depends on many abiotic and biotic factors, among which the adequate supply of micro nutrients is most important in Kinnow mandarin. Therefore a field trial was conducted to assess the effect of foliar application of different micronutrient concentrations on growth characteristics and shelf life of the Kinnow mandarin under rainfed conditions of Jammu. Experiment comprised of nine to ten year old plants on which different concentrations of micronutrients ( $\mathrm{Zn}, \mathrm{Fe}$ and $\mathrm{B}$ ) were applied through foliar feeding, individually or in combination. Results revealed that Kinnow mandarin trees sprayed with $0.4 \%$ $\mathrm{ZnSO}_{4}+0.6 \% \mathrm{FeSO}_{4}+0.2 \% \mathrm{H}_{3} \mathrm{BO}_{3}$ recorded maximum increase in plant height $(37.33 \mathrm{~cm})$, increase in trunk girth $(0.60 \mathrm{~mm})$ and increase in plant spread (NS: $28.43 \mathrm{~cm}$ and EW: $29.23 \mathrm{~cm})$. However, the highest increase in tree volume $\left(33.35 \mathrm{~m}^{3}\right)$ in Kinnow mandarin was obtained under treatment $0.4 \% \mathrm{ZnSO}_{4}+0.6 \%$ $\mathrm{FeSO}_{4}+0.4 \% \mathrm{H}_{3} \mathrm{BO}_{3}$. Lowest per cent physiological weight loss in fruits of Kinnow was recorded as $2.13 \%, 6.40 \%, 9.52 \%, 12.94 \%, 15.54 \%$ and $16.93 \%$ during $5^{\text {th }}, 10^{\text {th }}, 15^{\text {th }}, 20^{\text {th }}, 25^{\text {th }}$ and $30^{\text {th }}$ day of storage in the fruits treated with $0.4 \% \mathrm{ZnSO}_{4}+0.6 \% \mathrm{FeSO}_{4}+0.2 \% \mathrm{H}_{3} \mathrm{BO}_{3}$.

\section{Introduction}

Citrus fruits belonging to family Rutaceae and sub-family Aurantoideae have distinct flavors and therapeutic values. These are rich in vitamin $\mathrm{C}$ with fair amounts of vitamins $\mathrm{A}$ and B. Besides this, they are also good source of minerals like calcium, phosphorus and iron, etc. In India citrus is grown on about
1078 thousand hectare with an annual production of 11147 thousand metric tonnes (Anonymous, 2015). Though, different citrus species are cultivated in almost every state of India but Maharashtra, Andhra Pradesh, Karnataka, Assam and West Bengal are leading citrus growing states. Among the citrus species, Kinnow, a mandarin hybrid between King orange (Citrus nobilis Lour) 
and Willow leaf mandarin (Citrus deliciosa Tenore) is an economically important subtropical fruit, which is grown all over the arid and semi-arid regions of India having assured irrigation facilities. It is one of the most important fruit because of its juicy fruits, pleasant flavour and sour-sweet taste. It is freshly eaten and also used for processed into many products. Kinnow fruits are not only delicious and refreshing but also possesses great nutritive value containing 20-30 $\mathrm{mg} / 100 \mathrm{~g}$ vitamin $\mathrm{C}, 50.0 \mathrm{mg} / 100 \mathrm{~g}$ calcium, $20.2 \mathrm{mg} / 100 \mathrm{~g}$ phosphorus and $100 \mathrm{mg} / 100 \mathrm{~g}$ iron. Productivity of citrus trees depends on many abiotic (climate, site, soil, nutrition, and irrigation management) and biotic (rootstock, cultivar, insect pest and disease management) factors, among which the adequate supply of micro nutrients is most important in Kinnow mandarin. Zinc is an important microelement essential for plants due to its involvement in the synthesis of tryptophan which is a precursor of indole acetic acid. Zinc is required for the activity of various enzymes, such as dehydrogenases, aldolases, isomerases, transphosphorylases, RNA and DNA polymerases (Swietlik, 1999). Zinc deficiency is probably the most diffused nutritional alteration in all citrus producing areas. Iron plays a vital role in the synthesis of chlorophyll, carbohydrate production, cell respiration, reduction of nitrate sulphate and $\mathrm{N}$ assimilation. Boron as a micronutrient plays significant role in growth and productivity of citrus. The boron deficiency is mainly found in acidic and sandy soils, and those with low soil organic matter. Plant species differ dramatically in boron mobility, and may be classified into species with restricted boron mobility and those in which boron is highly mobile (Brown and Shelp, 1997). Foliar application of fertilizers is an ambitious pursuit for researchers and growers to maximize nutrient uptake by crops and minimizes fertilizer application and leaching loss. Foliar application of micronutrients like
$\mathrm{Zn}, \mathrm{Cu}, \mathrm{Mn}, \mathrm{B}$ and $\mathrm{Fe}$ has advantages over soil application because of high effectiveness, rapid plant response, convenience and elimination of toxicity symptoms brought about by excessive soil accumulation of such nutrients (Obreza et al., 2010). Curing micronutrient deficiencies through foliar application is a quick practice in getting better yield. Foliar application at key stages can have a marked positive effect on fruit yield and quality of fruits. Therefore studies were undertaken to assess the effect of zinc, iron and boron on tree characters and shelf life of Kinnow mandarin with the objectives to find out suitable zinc, iron and boron combination for optimum growth and production of Kinnow mandarin under rainfed conditions of Jammu.

\section{Materials and Methods}

The present investigation was carried out at the Rainfed Research Sub-station for Subtropical Fruits (RRSS) Raya, SUAST-J, J\&K, India during 2015-2016. The experimental field is situated at an elevation of $332 \mathrm{~m}$ above mean sea level and lies at $32^{\circ} 39^{\prime \prime N o r t h}$ latitude and 74 $53^{\circ}$ East longitude. The climate of experimental site is sub-tropical with hot and dry summer, hot and humid rainy season and cold winters. The maximum temperature rises up to $45^{\circ} \mathrm{C}$ during summer and minimum temperature falls upto $1{ }^{\circ} \mathrm{C}$ during winter. The mean annual rainfall is about 1000-1200 mm concentrated mainly during few weeks of rainy season (JulyAugust). Experiment comprised of 9-10 year old plants on which different concentrations of micronutrients were applied through foliar feeding, individually or in combination (T1: $0.2 \% \quad \mathrm{ZnSO}_{4}, \mathrm{~T} 2: 0.4 \% \quad \mathrm{ZnSO}_{4}, \mathrm{~T} 3: 0.6 \%$ $\mathrm{ZnSO}_{4}, \mathrm{~T} 4: 0.4 \% \quad \mathrm{FeSO}_{4}, \mathrm{~T} 5: 0.6 \% \quad \mathrm{FeSO}_{4}$, T6: $0.8 \% \mathrm{FeSO}_{4}$, T7: $0.2 \% \mathrm{H}_{3} \mathrm{BO}_{3}$, T8: $0.4 \%$ $\mathrm{H}_{3} \mathrm{BO}_{3}$, T9: $0.6 \% \mathrm{H}_{3} \mathrm{BO}_{3}$, T10: $0.2 \% \mathrm{ZnSO}_{4}+$ $0.4 \% \mathrm{FeSO}_{4}+0.2 \% \mathrm{H}_{3} \mathrm{BO}_{3}, \mathrm{~T} 11: 0.2 \%$ $\mathrm{ZnSO}_{4}+0.4 \% \mathrm{FeSO}_{4}+0.4 \% \mathrm{H}_{3} \mathrm{BO}_{3}, \mathrm{~T} 12$ : 
$0.2 \% \mathrm{ZnSO}_{4}+0.6 \% \mathrm{FeSO}_{4}+0.2 \% \mathrm{H}_{3} \mathrm{BO}_{3}$, T13: $0.2 \% \mathrm{ZnSO}_{4}+0.6 \% \mathrm{FeSO}_{4}+0.4 \%$ $\mathrm{H}_{3} \mathrm{BO}_{3}$, T14: $0.4 \% \mathrm{ZnSO}_{4}+0.4 \% \mathrm{FeSO} 4+$ $0.2 \% \quad \mathrm{H}_{3} \mathrm{BO}_{3}$, T15: $0.4 \% \quad \mathrm{ZnSO}_{4}+0.4 \%$ $\mathrm{FeSO}_{4}+0.4 \% \mathrm{H}_{3} \mathrm{BO}_{3}, \mathrm{~T} 16: 0.4 \% \mathrm{ZnSO}_{4}+$ $0.6 \% \mathrm{FeSO}_{4}+0.2 \% \quad \mathrm{H}_{3} \mathrm{BO}_{3}, \quad \mathrm{~T} 17: 0.4 \%$ $\left.\mathrm{ZnSO}_{4}+0.6 \% \mathrm{FeSO}_{4}+0.4 \% \mathrm{H}_{3} \mathrm{BO}_{3}\right)$ with each treatment replicated thrice. The control comprised of application of distilled water (T18). Fruit set in the orchard occurred during last week of April 2015 and the first spray was performed during second week of May 2015 and second spray after six weeks from the first spray. All the trees were maintained under uniform cultural schedule before and during the course of investigation. The experiment was statistically laid out as per the randomized block design. Increase in plant height was computed by subtracting the initial plant height recorded after fruit set during May 2015 (before 1st spray) and final plant height recorded at the time of fruit maturity with the help of measuring staff/ pole and expressed in per cent increase over the initial. Increase in plant spread was computed by subtracting the plant spread recorded in both the directions i.e. North-South and East-West during May 2015 (before 1st spray) from the final plant spread in both directions recorded at fruit maturity/harvest with the help of measuring staff/ pole and expressed in per cent increase over the initial in both the directions. Increase in trunk girth was computed by subtracting initial trunk girth recorded using the vernier calliper during May 2015 (before 1st spray) from final trunk girth during fruit maturity/ harvesting and expressed in terms of per cent increase over the initial. Increase in stock:scion ratio was calculated by subtracting the initial stock:scion ratio recorded using the vernier calliper during May 2015 (before 1st spray) from final stock:scion ratio during fruit maturity/ harvesting and expressed in terms of per cent increase over the initial. The increase in tree volume was worked out by subtracting the initial volume of the Kinnow mandarin tree worked out during May 2015 (before 1st spray) from final tree volume during fruit maturity/ harvesting and expressed in cubic meters. Number of fruits per tree was recorded by counting the number of fruits on a particular tree at the time of fruit maturity. Per cent fruit drop was calculated by dividing the difference of initial fruit set and final fruit retention multiplied with 100 . The crop load removed from the tree during harvesting season of 2015 was recorded as yield per tree and expressed in $\mathrm{kg} /$ plant. Shelf life of the fruit was observed by measuring the physiological loss in weight which was calculated as per the method suggested by Srivastava and Tondon (1968). The statistical analysis of the data generated during the course of study was analyzed as per the method suggested by Panse and Sukhatme (1967).

\section{Results and Discussion}

\section{Tree characters}

The data regarding effect of different treatments viz. zinc as zinc sulphate, iron as ferrous sulphate and boron as boric acid at different levels on tree characters of Kinnow mandarin has been recorded in table 1. The increase in plant height of Kinnow mandarin was significantly increased with different levels of zinc sulphate, ferrous sulphate and boric acid sprayed alone as well as in combination, over the control (distilled water spray). The maximum increase in plant height $(37.33 \mathrm{~cm})$ was recorded with the combined treatment of $0.4 \% \mathrm{ZnSO}_{4}+0.6 \% \mathrm{FeSO}_{4}+0.2 \%$ $\mathrm{H}_{3} \mathrm{BO}_{3}$ (T16) which was at par with treatments T14, T17 and T15 and was followed by treatments T12 $(33.87 \mathrm{~cm}), \mathrm{T} 10$ $(30.77 \mathrm{~cm}), \mathrm{T} 13(28.37 \mathrm{~cm})$ and T11 $(27.33$ $\mathrm{cm})$. Control resulted in minimum increase in plant height $(10.53 \mathrm{~cm})$. Among the individual treatments of $\mathrm{ZnSO}_{4}, \mathrm{FeSO}_{4}$ and 
$\mathrm{H}_{3} \mathrm{BO}_{3}$, the perusal of data in table 1 showed an increase in plant height with the increase in concentration level of zinc, iron and boron viz. T3 $(26.83 \mathrm{~cm})$, T2 $(24.73 \mathrm{~cm})$, T1 $(22.17$ $\mathrm{cm})$, T5 $(21.67 \mathrm{~cm}), \mathrm{T} 4(20.20 \mathrm{~cm})$, T6 $(17.73$ $\mathrm{cm}), \mathrm{T} 7(15.03 \mathrm{~cm}), \mathrm{T} 8(14.20 \mathrm{~cm})$ and T9 $(13.60 \mathrm{~cm})$ which was significantly higher than the control. Increase in plant height in the treated trees might be due to the active involvement of zinc in the synthesis of tryptophan which is a precursor of indole acetic acid synthesis, consequently it increased tissue growth and development (Swietlik, 1999). It has also been reported that sufficient level of zinc in plant promote the photosynthesis, nucleic acid metabolism and protein biosynthesis. Present findings are in agreement with Huda et al., (2009) who demonstrated that by adding zinc and iron, net photosynthetic rate and chlorophyll content of plants increased. Khan (2012) significantly increased the tree height of Feutrella Early mandarin trees with foliar application of boron and zinc when applied at fruit set stage. The increase in trunk girth of Kinnow mandarin tree was maximum $(0.60 \mathrm{~mm})$ with the combined treatment of $0.4 \% \mathrm{ZnSO}_{4}+0.6 \%$ $\mathrm{FeSO}_{4}+0.2 \% \mathrm{H}_{3} \mathrm{BO}_{3}$ (T16), which was at par with $0.58 \mathrm{~mm}$ increase in trunk girth under treatment $\mathrm{T} 14$ and $0.56 \mathrm{~mm}$ increase in trunk girth under treatment $\mathrm{T} 17$ and $0.55 \mathrm{~mm}$ increase in trunk girth under treatment T15 and followed by $0.53 \mathrm{~mm}$ increase in trunk girth under treatment T12, $0.52 \mathrm{~mm}$ under treatment T10, 0.45 under treatment T13and $0.43 \mathrm{~mm}$ in $\mathrm{T} 11$, while the minimum increase in trunk girth $(0.21 \mathrm{~mm})$ was obtained under the control treatment (T18). Separate sprays of zinc sulphate, ferrous sulphate and boric acid varied the increase in trunk girth of Kinnow mandarin with the increase in their concentration level. The treatments T3, T2, T1, T5, T4, T6, T7, T8 and T9 obtained an increase in trunk girth of $0.40 \mathrm{~mm}, 0.38 \mathrm{~mm}$, $0.36 \mathrm{~mm}, 0.34 \mathrm{~mm}, 0.31 \mathrm{~mm}, 0.30 \mathrm{~mm}, 0.29$ $\mathrm{mm}, 0.29 \mathrm{~mm}$ and $0.28 \mathrm{~mm}$ respectively.
Razzaq et al., (2013) observed that the Kinnow mandarin trees sprayed with $0.6 \%$ zinc sulfate exhibited the highest increase in stem girth as compared to all other treatments. Similarly, trees of Kinnow mandarin sprayed with $0.4 \%$ boric acid showed maximum increase in stem diameter than the control trees (Ullah et al., 2012). The increase in plant spread (NS) was maximum under the treatment T16, which was at par with 27.57 $\mathrm{cm}, 26.90 \mathrm{~cm}$ and $26.13 \mathrm{~cm}$ increase in plant spread (NS) under treatments T14, T17, and T15 respectively, and was followed by 24.23 $\mathrm{cm}, 23.80 \mathrm{~cm}, 23.30 \mathrm{~cm}$ and $22.97 \mathrm{~cm}$ increase in plant spread (NS) under treatments T12, T10, T13 and T11 respectively. The individual treatments of zinc sulphate and ferrous sulphate showed a significantly higher increase in plant spread (NS) with the increase in their concentration levels over control. An increase in plant spread (NS) in Kinnow mandarin of $19.90 \mathrm{~cm}, 20.53 \mathrm{~cm}$, $16.17 \mathrm{~cm}, 17.27 \mathrm{~cm}, 15.20 \mathrm{~cm}, 15.10 \mathrm{~cm}$, $15.00 \mathrm{~cm}$ and $14.83 \mathrm{~cm}$ was resulted under treatments T1, T2, T3, T4, T5, T6, T7, T8 and T9 respectively, as compared to control $(11.17 \mathrm{~cm})$. The foliar spray of zinc increased plant spread due to the fact that zinc spray activated the synthesis of protein, which are reported to protect chlorophyll destruction. Haque et al., (2000) also reported that the foliar spray of $\mathrm{ZnSO}_{4}(0.5 \%)$ and phosphoric acid $(0.1 \%)$ either alone or in combination with other nutrients $(\mathrm{Mg}$ and $\mathrm{Cu})$ on Mandarin showed effective increase in the plant height and plant spread. The increase in plant spread $(\mathrm{EW})$ of Kinnow mandarin was maximum $(29.33 \mathrm{~cm})$ under the treatment $\mathrm{T} 16$ which was at par with $28.30 \mathrm{~cm}$ increase in plant spread (EW) under treatment T14, 27.87 $\mathrm{cm}$ in $\mathrm{T} 17,27.60 \mathrm{~cm}$ in T15 and was followed by $26.37 \mathrm{~cm}$ increase in T12, $26.13 \mathrm{~cm}$ in $\mathrm{T} 10,25.30 \mathrm{~cm}$ in $\mathrm{T} 13$ and $24.43 \mathrm{~cm}$ in $\mathrm{T} 11$. The minimum increase in plant spread - EW $(11.40 \mathrm{~cm})$ was obtained under the control (distilled water spray) treatment. The 
individual treatments of $\mathrm{ZnSO} 4, \mathrm{FeSO} 4$ and H3BO3 at different levels on Kinnow mandarin showed a variation in plant spread (EW) with the increase in their concentration level over control. Treatment T3, T2, T1, T5, T4, T6, T9, T8 and T7 increased the plant spread (EW) to $23.50 \mathrm{~cm}, 20.63 \mathrm{~cm}, 19.60$ $\mathrm{cm}, 18.77 \mathrm{~cm}, 16.53 \mathrm{~cm}, 16.00 \mathrm{~cm}, 14.67 \mathrm{~cm}$, $14.90 \mathrm{~cm}$ and $15.30 \mathrm{~cm}$ respectively. These results are in conformity with those reported by Gurjar et al., (2015) in Kinnow mandarin. The higher increase in stock scion ratio of 0.04 was recorded in treatments $\mathrm{T} 17, \mathrm{~T} 16$, $\mathrm{T} 15, \mathrm{~T} 14, \mathrm{~T} 13, \mathrm{~T} 12, \mathrm{~T} 11$ and $\mathrm{T} 10$.

The increase in stock scion ratio of Kinnow mandarin as a result of zinc, iron and boron application sprayed alone as well as in combination was not significant over the control which might be because there was no sign of incompatibility between stock and scion of Kinnow mandarin tree therefore allowing free movement of nutrients across the union that might have helped both stock and scion grow equally. Thus, there was a proportionate increase in the stock and scion of Kinnow mandarin tree as a result of sprays of zinc sulphate, ferrous sulphate and boric. Maximum increase in tree volume $\left(33.35 \mathrm{~m}^{3}\right)$ was obtained under treatment $\mathrm{T} 17$ which was statistically at par with $33.28 \mathrm{~m}^{3}$ and $31.24 \mathrm{~m}^{3}$ increase in T16 and T15 respectively and was followed by $29.31 \mathrm{~m}^{3}$ increase in T14, 29.07 $\mathrm{m}^{3}$ in $\mathrm{T} 12,27.02 \mathrm{~m}^{3}$ in $\mathrm{T} 10,26.01 \mathrm{~m}^{3}$ in T13and $25.34 \mathrm{~m}^{3}$ in T11 and was significantly higher than control $\left(11.54 \mathrm{~m}^{3}\right)$.

Among the separate sprays of zinc sulphate, ferrous sulphate and boric acid, treatments T3, T2, T1, T5, T4, T6, T9, T8 and T7 showed an increase in tree volume of Kinnow mandarin of $22.20 \mathrm{~m}^{3}, 19.50 \mathrm{~m}^{3}, 19.10 \mathrm{~m}^{3}$, $18.22 \mathrm{~m}^{3}, 17.47 \mathrm{~m}^{3}, 16.00 \mathrm{~m}^{3}, 14.89 \mathrm{~m}^{3}$, $14.98 \mathrm{~m}^{3}$ and $15.36 \mathrm{~m}^{3}$, respectively which was significantly higher than the control. The increase in crown width may also be ascribed to zinc in its capacity as a constituent of carbonic anhydrase which is an important enzyme involved in the photosynthesis. The results are in agreement with those reported by Madarakhandi (2014).

The data presented in table 2 reveals that maximum number of fruits (153.33) per tree were obtained under treatment $\mathrm{T} 15$ which was followed by149.67 fruits per tree under treatment T11, 146.00 in T17, 141.67 in T13, 138.67 in $\mathrm{T} 14,137.67$ in $\mathrm{T} 12,137.00$ in T10and 130.33 in T16. The control treatment resulted in the minimum number of fruits (108.33) per tree. The higher fruit retention in zinc treated trees may be ascribed to an increase in the synthesis of indole acetic acid (IAA) which consequently improves the endogenous level of auxins at abscission zone to avoid fruit drop (Razzaq et al., 2013). The foliar application of boric acid increased the number of fruits per tree in Kinnow mandarin might be due to the increased fruit set and fruit retention by boron was also reported by Ullah et al., (2012).

The per cent fruit drop in Kinnow mandarin (Table 2 and Fig. 1) was minimum (7.78\%) under treatment $\mathrm{T} 17$ which was statistically at par with 8.53 per cent fruit dropin T15 and was followed by $9.93 \%, 10.53 \%, 12.76 \%$, $13.08 \%, 13.21 \%$ and $13.98 \%$ fruit drop under treatments $\mathrm{T} 13, \mathrm{~T} 11, \mathrm{~T} 14, \mathrm{~T} 16, \mathrm{~T} 12$ and $\mathrm{T} 10$ respectively. Maximum fruit drop of 26.30 per cent was found in the trees treated with distilled water. Among the separate sprays of zinc sulphate, ferrous sulphate and boric acid, the treatments T8, T7, T9, T2, T1, T3, T5, T4 and T6 resulted in fruit drop of $14.92 \%$, $15.06 \%, 17.06 \%, 19.65 \%, 20.22 \%, 20.77 \%$, $21.63 \%, 23.49 \%$ and $23.67 \%$ respectively which were significantly lower than the control. The findings are in conformity with those of Gurjar et al., (2015) in Kinnow mandarin. 
Table.1 Effect of foliar application of zinc, iron and boron on vegetative characters of Kinnow mandarin

\begin{tabular}{|c|c|c|c|c|c|c|}
\hline Treatment & $\begin{array}{l}\text { Increase in } \\
\text { plant height } \\
\text { (cm) }\end{array}$ & $\begin{array}{l}\text { Increase in } \\
\text { trunk girth } \\
\quad(\mathrm{mm})\end{array}$ & $\begin{array}{l}\text { Increase in plant } \\
\text { spread - NS }(\mathrm{cm})\end{array}$ & $\begin{array}{l}\text { Increase in plant } \\
\text { spread - EW }(\mathrm{cm})\end{array}$ & $\begin{array}{l}\text { Increase in stock } \\
\text { scion ratio }\end{array}$ & $\begin{array}{l}\text { Increase in tree } \\
\text { volume }\left(\mathbf{m}^{3}\right)\end{array}$ \\
\hline $\mathrm{T} 1$ & 22.17 & 0.36 & 19.90 & 19.60 & 0.03 & 19.10 \\
\hline $\mathrm{T} 2$ & 24.73 & 0.38 & 20.53 & 20.63 & 0.03 & 19.50 \\
\hline $\mathrm{T} 3$ & 26.83 & 0.40 & 22.83 & 23.50 & 0.03 & 22.20 \\
\hline $\mathrm{T} 4$ & 20.20 & 0.31 & 16.17 & 16.53 & 0.03 & 17.47 \\
\hline T5 & 21.67 & 0.34 & 17.27 & 18.77 & 0.03 & 18.22 \\
\hline T6 & 17.73 & 0.30 & 15.20 & 16.00 & 0.03 & 16.00 \\
\hline $\mathrm{T} 7$ & 15.03 & 0.29 & 15.10 & 15.30 & 0.03 & 15.36 \\
\hline $\mathrm{T} 8$ & 14.20 & 0.29 & 15.00 & 14.90 & 0.03 & 14.98 \\
\hline T9 & 13.60 & 0.28 & 14.83 & 14.67 & 0.03 & 14.89 \\
\hline $\mathrm{T} 10$ & 30.77 & 0.52 & 23.80 & 26.13 & 0.04 & 27.02 \\
\hline $\mathrm{T} 11$ & 27.33 & 0.43 & 22.97 & 24.43 & 0.04 & 25.34 \\
\hline T12 & 33.87 & 0.53 & 24.23 & 26.37 & 0.04 & 29.07 \\
\hline T13 & 28.37 & 0.45 & 23.30 & 25.30 & 0.04 & 26.01 \\
\hline $\mathrm{T} 14$ & 37.07 & 0.58 & 27.57 & 28.30 & 0.04 & 29.31 \\
\hline $\mathrm{T} 15$ & 36.03 & 0.55 & 26.13 & 27.60 & 0.04 & 31.24 \\
\hline T16 & 37.33 & 0.60 & 28.43 & 29.23 & 0.04 & 33.28 \\
\hline $\mathrm{T} 17$ & 36.53 & 0.56 & 26.90 & 27.87 & 0.04 & 33.35 \\
\hline $\mathrm{T} 18$ & 10.53 & 0.21 & 11.17 & 11.40 & 0.03 & 11.54 \\
\hline $\mathrm{CD}_{0.05}$ & 1.45 & 0.05 & 3.08 & 2.20 & NS & 2.36 \\
\hline
\end{tabular}


Table.2 Effect of foliar application of zinc, iron and boron on fruit retention/ drop and fruit yield of Kinnow mandarin

\begin{tabular}{|c|c|c|c|c|c|}
\hline Treatment & $\begin{array}{c}\text { Number of fruits per } \\
\text { tree } \\
\text { (before spray) }\end{array}$ & $\begin{array}{c}\text { Number of fruits } \\
\text { per tree } \\
\text { (at harvest stage) }\end{array}$ & $\begin{array}{l}\text { Number of fruits } \\
\text { dropped }\end{array}$ & $\begin{array}{l}\text { Fruit drop } \\
\qquad(\%)\end{array}$ & $\begin{array}{l}\text { Fruit yield } \\
\text { per tree } \\
(\mathrm{kg})\end{array}$ \\
\hline $\mathrm{T} 1$ & 140.00 & 111.67 & 28.33 & 20.22 & 12.70 \\
\hline $\mathrm{T} 2$ & 149.00 & 119.67 & 29.33 & 19.65 & 13.78 \\
\hline $\mathrm{T} 3$ & 158.67 & 125.67 & 33.00 & 20.77 & 14.59 \\
\hline $\mathrm{T} 4$ & 150.33 & 115.00 & 35.33 & 23.49 & 12.59 \\
\hline T5 & 147.67 & 115.67 & 32.00 & 21.63 & 12.94 \\
\hline T6 & 157.67 & 120.33 & 37.33 & 23.67 & 12.97 \\
\hline $\mathrm{T} 7$ & 157.00 & 133.33 & 23.67 & 15.06 & 14.21 \\
\hline T8 & 160.33 & 136.33 & 24.00 & 14.92 & 14.39 \\
\hline T9 & 156.00 & 129.33 & 26.67 & 17.06 & 13.62 \\
\hline $\mathrm{T} 10$ & 159.33 & 137.00 & 22.33 & 13.98 & 16.97 \\
\hline $\mathrm{T} 11$ & 167.33 & 149.67 & 17.67 & 10.53 & 17.74 \\
\hline $\mathrm{T} 12$ & 158.67 & 137.67 & 21.00 & 13.21 & 17.55 \\
\hline $\mathrm{T} 13$ & 157.33 & 141.67 & 15.67 & 9.93 & 17.34 \\
\hline T14 & 159.00 & 138.67 & 20.33 & 12.76 & 19.89 \\
\hline $\mathrm{T} 15$ & 167.67 & 153.33 & 14.33 & 8.53 & 20.10 \\
\hline T16 & 150.00 & 130.33 & 19.67 & 13.08 & 20.54 \\
\hline $\mathrm{T} 17$ & 158.33 & 146.00 & 12.33 & 7.78 & 19.59 \\
\hline $\mathrm{T} 18$ & 147.00 & 108.33 & 38.67 & 26.30 & 10.87 \\
\hline $\mathrm{CD}_{0.05}$ & & 1.19 & & 0.87 & 0.55 \\
\hline
\end{tabular}


Table.3 Effect of foliar application of zinc, iron and boron on physiological loss in weight of Kinnow mandarin

\begin{tabular}{|c|c|c|c|c|c|c|}
\hline \multirow[t]{2}{*}{ Treatments } & \multicolumn{6}{|c|}{ Percentploss in weight after storage } \\
\hline & $5^{\text {th }}$ day & $10^{\text {th }}$ day & $15^{\text {th }}$ day & $20^{\text {th }}$ day & $25^{\text {th }}$ day & $30^{\text {th }}$ day \\
\hline $\mathrm{T} 1$ & 4.71 & 9.72 & 14.30 & 16.86 & 20.04 & 21.30 \\
\hline $\mathrm{T} 2$ & 4.59 & 9.60 & 13.54 & 16.79 & 19.31 & 20.61 \\
\hline $\mathrm{T} 3$ & 4.15 & 9.17 & 12.25 & 15.55 & 18.07 & 19.40 \\
\hline $\mathrm{T} 4$ & 5.00 & 10.08 & 14.72 & 17.93 & 20.42 & 21.70 \\
\hline T5 & 4.98 & 9.96 & 14.67 & 17.88 & 20.35 & 21.65 \\
\hline T6 & 5.23 & 10.57 & 15.32 & 18.53 & 20.98 & 22.20 \\
\hline $\mathrm{T} 7$ & 5.42 & 10.19 & 15.11 & 18.30 & 20.75 & 22.05 \\
\hline T8 & 5.62 & 10.74 & 15.35 & 18.52 & 20.99 & 22.27 \\
\hline T9 & 5.80 & 10.87 & 15.79 & 18.96 & 21.39 & 22.65 \\
\hline T10 & 3.01 & 8.09 & 11.93 & 15.25 & 17.80 & 19.12 \\
\hline T11 & 3.77 & 8.72 & 12.17 & 15.47 & 18.00 & 19.33 \\
\hline T12 & 2.86 & 7.93 & 11.67 & 14.99 & 17.55 & 18.76 \\
\hline $\mathrm{T} 13$ & 3.56 & 8.60 & 12.15 & 15.45 & 17.99 & 19.32 \\
\hline T14 & 2.42 & 7.54 & 10.59 & 13.96 & 16.55 & 17.89 \\
\hline T15 & 2.57 & 7.66 & 11.38 & 14.72 & 17.28 & 18.62 \\
\hline T16 & 2.13 & 6.40 & 9.52 & 12.94 & 15.54 & 16.93 \\
\hline T17 & 2.56 & 7.66 & 10.93 & 14.28 & 16.86 & 18.20 \\
\hline T18 & 6.92 & 12.18 & 16.21 & 19.36 & 21.79 & 23.07 \\
\hline $\mathrm{CD}_{0.05}$ & 0.26 & 0.08 & 0.04 & 0.05 & 0.04 & 0.55 \\
\hline
\end{tabular}



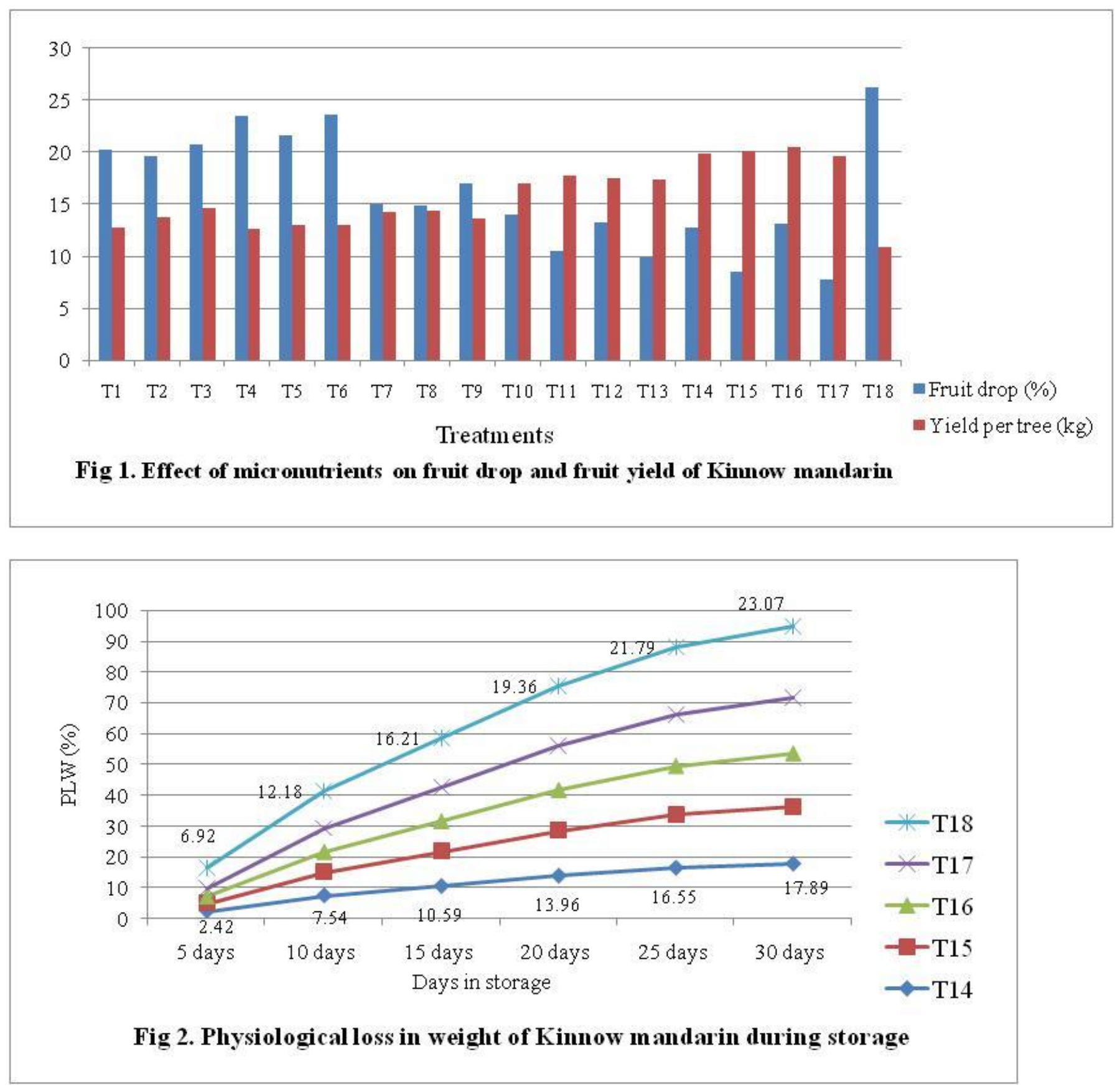
The fruit yield per tree was maximum (20.54 $\mathrm{kg}$ ) under treatment $\mathrm{T} 16$ which was statistically at par with $20.10 \mathrm{~kg}$ in $\mathrm{T} 15$ followed by $19.89 \mathrm{~kg}$ in $\mathrm{T} 14,19.59 \mathrm{~kg}$ in T17, $17.74 \mathrm{~kg}$ in $\mathrm{T} 11,17.55 \mathrm{~kg}$ in T12, $17.34 \mathrm{~kg}$ in $\mathrm{T} 13$ and $16.97 \mathrm{~kg}$ in $\mathrm{T} 10$ which was significantly higher than $10.87 \mathrm{~kg}$ fruit yield obtained under control (T18). The fruit yield per tree also increased with the separate treatments of $\mathrm{ZnSO}_{4}, \mathrm{FeSO}_{4}$ and $\mathrm{H}_{3} \mathrm{BO}_{3}$ wherein $14.21 \mathrm{~kg}$ obtained in $\mathrm{T} 7,14.39 \mathrm{~kg}$ in $\mathrm{T} 8,13.62 \mathrm{~kg}$ in $\mathrm{T} 9,14.59 \mathrm{~kg}$ in $\mathrm{T} 3,13.78 \mathrm{~kg}$ in $\mathrm{T} 2,12.70 \mathrm{~kg}$ inT1, $12.97 \mathrm{~kg}$ in T6, 12.94 $\mathrm{kg}$ in $\mathrm{T} 5$ and $12.59 \mathrm{~kg}$ in $\mathrm{T} 4$ which was significantly higher than $10.87 \mathrm{~kg}$ under control (T18). Foliar application of micronutrients might have corrected the deficiencies leading to optimum physiological activities of plant which might have resulted into higher production of fruits in treated plants. The increase in fruit yield with foliar application of zinc sulfate may be ascribed to increase in the fruit retention on the tree consequently reduced the pre-harvest fruit drop. Razzaq et al., (2013) reported that spray applications of $0.4 \%$ and $0.6 \%$ zinc sulphate resulted in the higher numbers and percentage of marketable fruit compared to control trees. These results are in close conformity with the findings of Gaur et al., (2014). The significant increase in fruit yield $(\mathrm{kg} / \mathrm{tree})$ of Kinnow mandarin is a cumulative effect of increase in number of fruits because of reduction in fruit drop by the direct and indirect effect of foliar spray of micronutrients.

\section{Shelf life}

Shelf life of the fruit was observed through percent physiological loss in weight of fruit.The data presented in table 3 and figure 2 reveal that with the advancement of storage life, the per cent weight loss was highly significant. The treatment T16 resulted in minimum physiological loss in weight of fruit i.e. $2.13 \%, 6.40 \%, 9.52 \%, 12.94 \%, 15.54 \%$ and $16.93 \%$ ) during $5^{\text {th }}, 10^{\text {th }}, 15^{\text {th }}, 20^{\text {th }}, 25^{\text {th }}$ and $30^{\text {th }}$ day of storage which was followed by physiological loss in weight under treatments T14, T17, T15, T12, T10, T13, T11 whereas the control (distilled water spray) treatment resulted in the highest physiological weight loss $(6.92 \%, 12.18 \%$, $16.21 \%, 19.36 \%, 21.79 \%$ and $23.07 \%$ on $5^{\text {th }}$, $10^{\text {th }}, 15^{\text {th }}, 20^{\text {th }}, 25^{\text {th }}$ and $30^{\text {th }}$ day of storage respectively). The separate sprays of $\mathrm{ZnSO}_{4}$, $\mathrm{FeSO}_{4}$ and $\mathrm{H}_{3} \mathrm{BO}_{3}$ also lowered the physiological weight loss of Kinnow fruits under storage conditions. The reduced per cent spoilage in fruits with foliar application of 0.3 per cent zinc sulphate has also been observed in guava by Chaitanya et al., (1997). It may be due to the better nutrition to the treated plants which ultimately have decreased the physiological weight loss in fruits. Goswami et al., (2012) also reported minimum physiological weight loss $(2.28 \%)$ in fruits treated with 0.4 per cent zinc sulphate followed by 2.42 percent physiological weight loss in fruits treated with boric acid at 0.4 per cent.

\section{References}

Anonymous. 2015. National Horticulture Board Database 2014, Ministry of Agriculture, Government of India, Gurgaon, India.

Brown, P. H. and Shelp, B. J. 1997. Boron mobility in plants. Plant and Soil. 193: 85-101.

Chaitanya, C. G., Kumar, G., Raina, B. L. and Muthoo, A. K. 1997.Effect of foliar application of zinc and boron on yield and quality of guava cv. Lucknow-49 (Sardar). Haryana J. Hort. Sci. 26 (1-2): 78-80.

Gaur, B., Beer, K. H, Tejraj S., Kanth, N. and Syamal, M. M. 2014.Studies on the effect of foliar application of nutrients and GA3 on fruit yield and quality of winter season guava. An Int. Qrt. J. Env. 
Sci.6: 479-83.

Goswami, A. K., Shukla, H. S., Kumar, P. and Mishra, D. S. 2012. Effect of preharvest application of micronutrients on quality of guava (Psidium guajava L.) cv. Sardar. Hort Flora Res. Spectrum, 1 (1): 60-63.

Gurjar, M. K., Kaushik, R. A. and Baraily, P. 2015. Effect of zinc and boron on the growth and yield of Kinnow mandarin. Int. J. of Scientific Res.4 (4): 207-08.

Haque, R., Roy, A. and Pramanic, M. 2000. Response of foliar application of $\mathrm{Mg}$, $\mathrm{Zn}, \mathrm{Cu}$ and $\mathrm{B}$ on improvement of growth, yield and trial quality of Mandarin orange in Darjeeling Hills of West Bengal. Hort. J.13 (2):15-20.

Huda, K. M. K., Bhuiyan, M. S. R., Zeba, N., Banu, S.A., Mahmud, F., and Khatun, A. 2009. Effect of $\mathrm{FeSO}_{4}$ and $\mathrm{pH}$ on shoot regeneration from the cotyledon explants of Tossa Jute. Pl. Omics J.2 (5): 190-96.

Khan, A. S., Ullah, W., Malik, A. U., Ahmad, R., Saleem, B. A. And Rajwana, I. A. 2012. Exogenous applications of boron and zinc influence leaf nutrient status, tree growth and fruit quality of Feutrella
Early (Citrus reticulate Blanco). Pak. J. of Agri. Sci.49 (2): 113-19.

Madarakhandi, S., Patil, D. R., Shafeeq, L. B. and Swamy, G. S. K. 2014.Studies on the influence of micronutrient on growth, yield and quality of Kinnow mandarin. Trends in Biosciences, 7 (9): 786-88.

Obreza, T. A., Zekri, M., Hanlon, E. A., Morgan, K., Schumann, A. and Rouse, R. 2010.Soil and leaf tissue testing for commercial citrus production. University of Florida Extension Service. SL253.04.

Panse, V. G. and Sukhatme, P. V. 1967.Stastistical method for agricultural workers. $2^{\text {nd }}$ Edition, ICAR publication, New Delhi. 381 p.

Srivastava, M. P. and Tondon, R. N. 1968. Influence of temperature in Botryoplodia rot of citrus and Sapodilla. Ind. Phytopathology, 21: 195- 97.

Swietlik, D. 1999. Zinc nutrition in horticultural crops. In: J. Janick (ed.). Horticultural Reviews. John Wiley \& Sons, Inc. pp. 109-18.

\section{How to cite this article:}

Kumari, P., M. Jamwal, N. Sharma, V. B. Singh and Gupta, N. 2020. Effect of Micronutrient Application on Growth, Fruit Retention and Shelf Life of Kinnow (Citrus reticulata Blanco.) Mandarin under Rainfed Conditions. Int.J.Curr.Microbiol.App.Sci. 9(08): 2707-2717. doi: https://doi.org/10.20546/ijcmas.2020.908.307 